\title{
Shaft Inserting into Moving Object Using Robot Equipped end Effector with Position Error Sensor
}

\author{
Yuichi Yamada Student Member （Toyota Technological Institute, 7syama@toyota-ti.ac.jp) \\ Soichiro Hayakawa Member (Toyota Technological Institute, s_hayakawa@toyota-ti.ac.jp) \\ Nuio Tsuchida Member (Toyota Technological Institute, s7tsuci@toyota-ti.ac.jp)
}

Keywords: one dimensional PSD, moving object, end effector, shaft inserting

We had developed the cross PSD sensor that could detect the position error between centers of the shaft and the target hole in real time. The shaft inserting robot system with the cross PSD sensor could insert the shaft into the moving hole at the speed of $80 \mathrm{~mm} / \mathrm{sec}$ with the clearance of $50 \mu \mathrm{m}$. However, the center of the cross PSD sensor did not coincide with the center of the shaft in this system. Therefore, the sensor could not detect the position error during the shaft inserting operation. It was very serious problem for shaft inserting.

In order to overcome this problem, we propose a new position error sensor in which four 1 dimensional PSDs are arranged in cross. At first, we show the detecting principle of the proposed new PSD sensor. The structure of the one dimensional PSD sensor is shown in Fig. 1. This sensor has 64 IR-LEDs for lighting the target with the hole. When the target hole is lit by IR-LEDs, the black image of hole is focused on the one dimensional PSD. By moving of the target hole, the hole image also moves. The outputs of PSD depending on the position of hole image are to change. Therefore, the sensor can detect the position error between the both centers of the sensor and the target hole. When the distance between the target hole and the PSD changes, the center of the black image of hole moves from the center of the one dimensional PSD named $\mathrm{PSD}_{\mathrm{XL}}$, since the sensor dose not watch the target from the front. Then the sensor cannot detect the position of the hole center.

In order to avoid this problem, another one dimensional PSD, named $\mathrm{PSD}_{\mathrm{XR}}$, is set in the opposite side of the shaft, and we get the current difference between two PSDs as the sensor output. The changing output of PSD can be canceled by setting two PSDs symmetrically for shaft, even if the distance between the target hole and the PSD is changed. Therefore, the differential value of currents between two PSDs becomes zero in the case of no position error. To detect the position error in directions $\mathrm{X}$ and $\mathrm{Y}$, the sensor is built by arranging four 1 dimensional PSDs in cross.

Then, the output characteristic of the developed sensor system was investigated. The relationship between the position error along $\mathrm{X}$ axis and the sensor output is shown in Fig. 2. The distance between the hole and the sensor head was changed from $40 \mathrm{~cm}$ to $70 \mathrm{~cm}$ at $10 \mathrm{~cm}$ intervals. The vertical axis shows the sensor output. The horizontal axis shows the position error. Even if the distance between the hole and the sensor head is changed, the sensor output is zero at no position error. From these results, this sensor can be used to control the peg-in-hole robot system for the moving object. We constructed the peg-in-hole robot system equipped the end effector with the developed sensor system.

We made experiment on shaft inserting for a moving object. The velocity of the target hole is set to $80 \mathrm{~mm} / \mathrm{sec}$. The clearance between the shaft and the hole is $50 \mu \mathrm{m}$, and the hole had no chamfering. Ten times of trial of the shaft insertion for the moving object was executed. The success rate of the shaft insertion was $100 \%$. Our proposed sensor system is effective in the shaft insertion for the moving object by using robot manipulator.

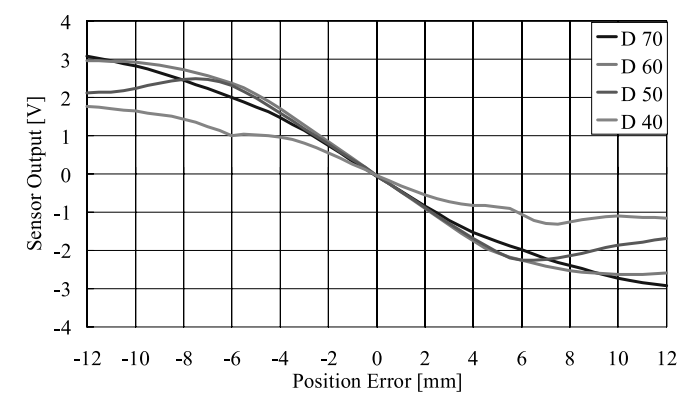

Fig. 2. Experimental result for position error output

Fig. 1. Structure of one dimensional PSD sensor 


\title{
位置誤差センサ内蔵エンドエフェクタを搭載したロボットによる 移動物体への軸扦入作業
}

\author{
学生員 山田 裕一* 正 員 早川聡一郎* \\ 正 員 土田 縫夫*
}

\author{
Shaft Inserting into Moving Object Using Robot Equipped End Effector with \\ Position Error Sensor
}

Yuichi Yamada*, Student Member, Nuio Tsuchida*, Member, Nuio Tsuchida*, Member

\begin{abstract}
Shaft inserting is important and frequent operation for the automatic parts assembling. Because our proposed cross PSD sensor can not detect the position error during the shaft inserting, we propose the new position sensor system by using one dimensional PSDs. This sensor can detect the position error between the center of the shaft and the center of the hole in real time. First, we show the detecting principle of this sensor and structure of the end effector with this sensor. The center of the sensor coincides with the center of the shaft. The sensor can detect the position error when the distance between the target hole and the sensor changes. So this sensor can detect position error during shaft inserting. Next, we show the configuration of the robot system with the end effector. By using this robot system, the robot can insert the shaft into the hole of the moving object with the clearance of $50 \mu \mathrm{m}$ at a velocity of $80 \mathrm{~mm} / \mathrm{s}$. Though the proposed sensor system is simple structure, it is effectiveness for the shaft inserting into the hole of the moving object.
\end{abstract}

キーワード : 一次元 PSD, 移動物体, エンドエフェクタ, 軸挿入

Keywords: one dimensional PSD, moving object, end effector, shaft inserting

\section{1.はじめに}

産業用ロボットの製品組立において，ボルト穴などへの シャフト挿入は重要な作業である。これまで peg-in-hole 問 題については多くの研究がなされているが，そのほとんど の研究が静止物体に対する研究 ${ }^{(1) \sim(4)}$ で, 移動物体に対する はめ合い作業の研究はほとんど行なわれていない ${ }^{(5)}$ 。

著者らは従来より移動物体に対するはめ合い作業の実現 を目的として研究を行ってきた (6)(7)。移動物体に対するは め合い作業において, 組立対象となる穴の重心位置を高速 高精度に検出する位置決めセンサとして使用できる十字型 PSD (Position Sensitive Detector) センサを提案・開発し た ${ }^{(8)}$ 。そして, その十字型 PSD センサを装着したロボット システムを構築し, 速度 $40 \mathrm{~mm} / \mathrm{s}$ で移動する挿入軸とのク リアランス $100 \mu \mathrm{m}$ の穴に対してはめ合い作業を行なうこ とに成功した。さらに，軸挿入性能向上のため移動物体に 対する組立作業用のエンドエフェクタとして振動型エンド エフェクタ(9) を提案・開発した。この振動型エンドエフェ

\footnotetext{
*豊田工業大学

干 468-8511 名古屋市天白区久方 2-12-1

Toyota Technological Institute

2-12-1, Hisakata, Tempaku-ku, Nagoya 468-8511
}

クタと十字型 PSD センサを装着したロボットマニピュレー 夕によって, 速度 $80 \mathrm{~mm} / \mathrm{s}$ で移動する, 軸とのクリアラン ス $50 \mu \mathrm{m}$ の穴に対して軸挿入可能なシステムを実現した。 しかし，この軸挿入システムでは十字型 PSD センサと挿入 軸が上下の位置関係で取り付けられており, 軸の重心とセ ンサの重心が一致していない。このため, 軸挿入動作中は 対象穴位置の測定が長時間不可能となる。したがって, 軸 挿入中にセンシングを行っていないことから, 外乱等の環 境変化が生じた場合に軸挿入の失敗につながる。このこと は軸挿入作業にとって非常に大きな問題である。

本論文では, 前述の問題を解決する新しい位置誤差検出 用 PSD センサシステムの開発を目的とする。はじめに, 一 次元 PSD を用いた穴面位置検出アルゴリズムを提案し，そ の理論を説明する。さらに，このアルゴリズムを用いて一 次元 PSD を十字形状に 4 つ配置し, センサ重心と挿入軸 重心を一致させた位置誤差検出センサを提案する。そのセ ンサシステムを市販の一次元 PSD を用いて製作し，そのセ ンサを搭載したエンドエフェクタを構築する。市販の一次 元 PSD を使用することでより簡単にセンサシステムの構 築が可能となる。また, 一次元 PSD を十字形状に 4 つ配 置したことで，軸の重心とセンサの重心が一致することか ら，軸挿入動作中でも対象穴位置の測定が可能となり，従 
来の十字型 PSD センサの問題点を解消することができる。 最後に，本センサシステムを搭載したエンドエフェクタシ ステムを構築し，製作した位置誤差検出センサ内蔵エンド エフェクタをロボットマニピュレータに取り付けて，移動 物体に対する軸挿入実験を行い有効性の検証を行なう。

\section{2. 一次元 PSD を用いた位置誤差検出センサ}

$\langle 2 \cdot 1\rangle$ 一次元 PSD による重心位置誤差検出 一次元 PSD は横に細長い受光面とその両端に電極を持つ構造と なっている。その構造を図 1 に示す。図 1 で一次元 PSD の中心から距離 $X_{s}$ だけずれた点にスポット光が入射した 場合，一次元 PSD の等価回路は図 2 のようになる。ここで $L$ は一次元 PSD の中心から端部電極までの長さであり， $R_{a}$ はその一次元 PSD の受光面の抵抗層の半分の長さの抵抗值 である。受光面は均一な抵抗層で, 幅は限りなく狭い物と 仮定する。スポット光が受光面に入射した部分では，光電 効果により電流 $I_{0}$ が発生する。スポット光が入射した点か ら各電極までの抵抗值はその距離に比例する。この抵抗值 の違いから，一次元 PSD の両電極に流れ出す電流值は分流 の法則を使い,

$$
\begin{aligned}
& I_{X r}=I_{0} \frac{L+X_{s}}{2 L} \\
& I_{X l}=I_{0} \frac{L-X_{s}}{2 L}
\end{aligned}
$$

として求まる。ただ， $I_{X r}$ は一次元 PSD の右電極 $X_{R}$ よ り流れ出る電流を示し, $I_{X l}$ は一次元 PSD の左電極 $X_{L}$ より 流れ出る電流を示す。これらの電流值を用いると，スポッ

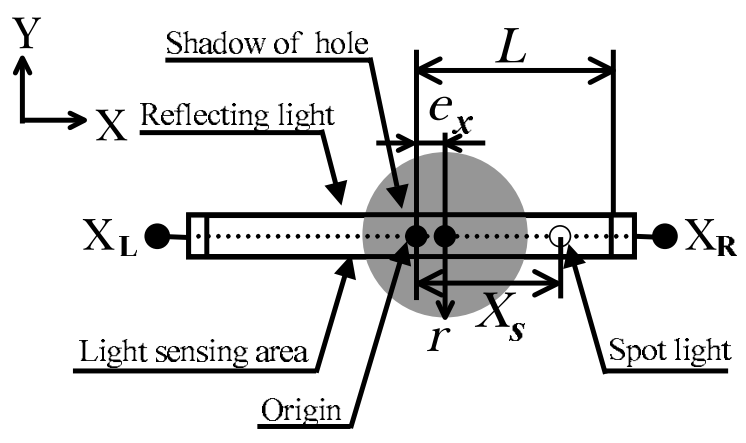

図 1 一次元 PSD 表面の影の様子

Fig. 1. The one dimensional PSD on which the shadow of the hole image is focused.

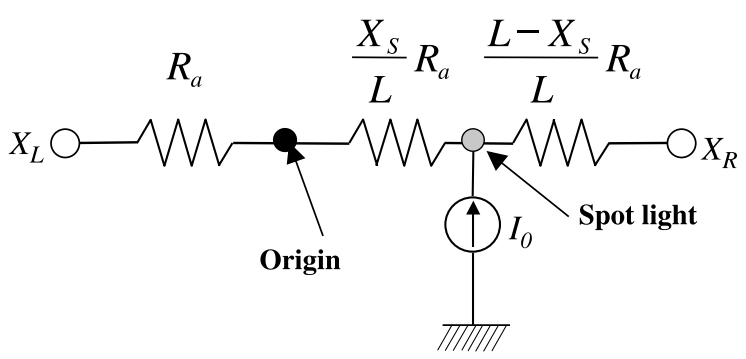

図 2 一次元 PSD の等価回路

Fig. 2. Equivalent circuit of one dimensional PSD
ト光の入射位置 $X_{S}$ は以下のように求まる。

$$
\frac{I_{X r}-I_{X l}}{I_{X r}+I_{X l}}=\frac{1}{L} X_{s}
$$

次に，穴面に対して赤外光を照射し，その反射光を一次 元 PSD 表面に受光した図 1 の状態を考える。ここで, 影と なる部分が光を反射しない穴の部分であり，それ以外の受 光面には反射光が入射している。このとき一次元 PSD上の 受光面上に入射した反射光により発生する電流が電極 $\mathrm{X}_{R}$ と $\mathrm{X}_{L}$ より流れ出す值を求める。図中, $r$ が穴面の半径, $e_{x}$ が穴面の中心が一次元 PSD の中心からどれだけ離れている かの距離を表す。(1)式を用いて受光面上の反射光入射領域 を積分することで $X_{R}$ 電極より発生する電流総量 $I_{X R}$ は以 下のように求まる。

$$
\begin{aligned}
I_{X R}= & \int_{r+e_{x}}^{L} I_{X r} d X_{s}+\int_{-L}^{-r-e_{x}} I_{X r} d X_{s} \\
= & \int_{r+e_{x}}^{L} I_{0} \frac{L+X_{s}}{2 L} d X_{s}+\int_{-L}^{-r-e_{x}} I_{0} \frac{L+X_{s}}{2 L} d X_{s} \\
= & \frac{I_{0}}{2}\left(L-r-e_{x}\right)\left\{1+\frac{1}{2 L}\left(L+r+e_{x}\right)\right\} \\
& +\frac{I_{0}}{2}\left(L-r+e_{x}\right)\left\{1-\frac{1}{2 L}\left(L+r-e_{x}\right)\right\} \ldots \ldots
\end{aligned}
$$

さらに(2) 式を用いて同様に受光面上を積分することで $X_{L}$ 電極より発生する電流総量 $I_{X L}$ が求まる。

$$
\begin{aligned}
I_{X L}= & \frac{I_{0}}{2}\left(L-r-e_{x}\right)\left\{1-\frac{1}{2 L}\left(L+r+e_{x}\right)\right\} \\
& +\frac{I_{0}}{2}\left(L-r+e_{x}\right)\left\{1+\frac{1}{2 L}\left(L+r-e_{x}\right)\right\} .
\end{aligned}
$$

スポット光の入射位置を求めた場合の (3) 式と同様に $\left(I_{X R}-I_{X L}\right) /\left(I_{X R}+I_{X L}\right)$ を求めることにより, 影の重心位置 誤差と出力電流の関係は以下の式として求められる。

$$
\begin{aligned}
\frac{I_{X R}-I_{X L}}{I_{X R}+I_{X L}}= & \frac{-r}{L^{2}-L r} e_{x} \\
& \left(-L+r<e_{x}<L-r\right)
\end{aligned}
$$

この式の右辺は $e_{x}$ 以外は全て定数であることから, 受光面 に入射した影の穴の位置誤差 $e_{x}$ と一次元 PSD の電極に流 れる電流值で演算した式は線形の関係にあることが分かる。 同様に，穴の影が一次元 PSD の受光面の右端からはみ出た 状態や左端からはみ出た状態の場合についても求められ,

$$
\begin{aligned}
\frac{I_{X R}-I_{X L}}{I_{X R}+I_{X L}}= & -\frac{1}{2 L}\left(L+r-e_{x}\right) \\
& \left(L>e_{x}>L-r\right) \cdots \\
\frac{I_{X R}-I_{X L}}{I_{X R}+I_{X L}}= & \frac{1}{2 L}\left(L+r+e_{x}\right) \\
& \left(-L<e_{x}<-L+r\right)
\end{aligned}
$$

という関係式が得られる。

穴の実際の半径を $r_{g}$, 一次元 PSD に投影される穴の影の 半径を $r$ としたとき, PSD センサ表面上の影の誤差 $e_{x}$ と実 際の穴の位置誤差 $e_{r x}$ との関係は次式のように求められる。 


$$
e_{x}=\frac{r}{r_{g}} e_{r x}
$$

光学系の設計は図 3 に示すように挿入軸と穴面を対向させ, 一次元 PSD は穴を斜めから見る構成にした。レンズ部と 対象穴面の距離を $70 \mathrm{~mm}$ と設定した場合に，対象穴の半径 $r_{g}$ が $5.70 \mathrm{~mm}$ に対して, 受光面上に結象される穴の影の半 径 $r$ を $2.28 \mathrm{~mm}$ となるように光学系を設計した。(6)～(9) 式に実際に使用した一次元 PSD のサイズ $L$ を $6.00 \mathrm{~mm}$ と し，また上記のそれぞれのパラメータを代入して計算する と図 4 のような $\left(I_{X R}-I_{X L}\right) /\left(I_{X R}+I_{X L}\right)$ と $e_{r X}$ の関係が得ら れる。この図において，横軸が実際の穴面と挿入軸の位置 誤差, 縦軸が理論出力值を示している。

この図を見ると，位置誤差の大きさが $9 \mathrm{~mm}$ 以上となる と, 正負どちらの誤差の領域でもセンサ出力特性の傾きが 変化する特徵を持っていることが分かる。この領域を使用 するような状況になっても，七ンサ出力值の大きさこそ変 化するが符号変化はないため制御に大きな問題は生じない。

$\langle\mathbf{2} \cdot \mathbf{2}\rangle$ 出力差分方式による位置誤差検出法 図 3 に示 すように, 軸と一次元 PSD の位置関係より一次元 PSD が対 象穴面を斜めから見る構成としたため, 図 5(a) の $\mathrm{PSD}_{X L}$ で 示される一次元 PSD 出力のように，光学系を穴面と一次元 PSD のある設定距離 A のとき位置誤差 0 で出力 0 になるよ う調整しても（本センサの場合その距離は $70 \mathrm{~mm}$ ), 対象穴 と一次元 PSD センサの距離が B に変化した場合には影の

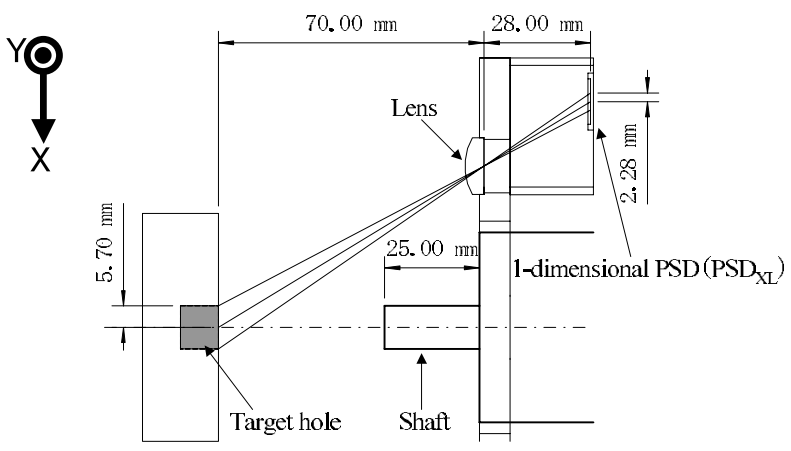

図 3 一次元 PSD の光学系

Fig. 3. Optical system of one dimensional PSD.

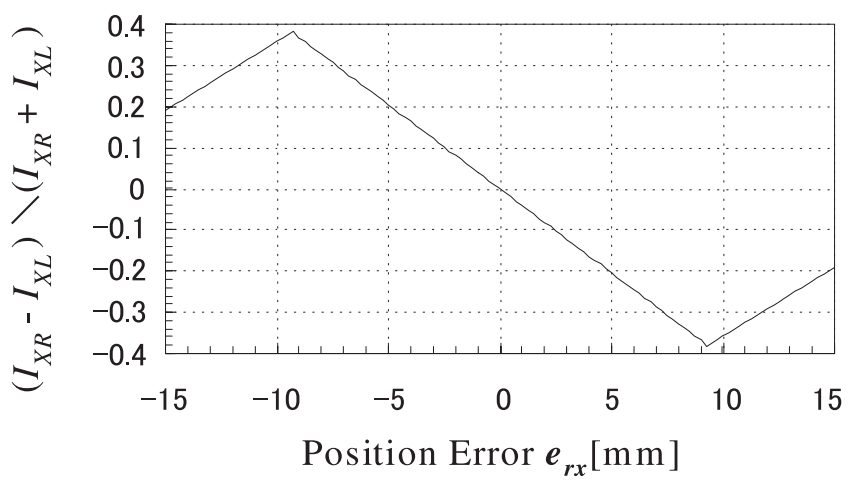

図 4 位置誤差の理論出力

Fig. 4. Theoretical output of position error.
重心位置が一次元 PSD の中心よりずれ, 図 5(b) の $\mathrm{PSD}_{X L}$ のように位置誤差 0 で出力 0 とならなくなる。すなわち, 対象穴面とセンサの距離が変動すると位置䛊差 0 とする制 御に使用できなくなる。この問題を回避するため, 挿入軸 を中心として対称の位置にもう一つの一次元 PSD $\left(\mathrm{PSD}_{X R}\right)$ を配置し，2つの一次元 PSD 出力の差分值を使用すること を考えた。その一次元 PSD の配置を図 6 に示す。挿入軸 に対して対称的な位置に $2 つ 0 一$ 次元 $\mathrm{PSD}_{X L}$ と $\mathrm{PSD}_{X R}$ を 取り付ける。これより, 図 5(a), (b) 中の $\mathrm{PSD}_{X L}, \mathrm{PSD}_{X R}$ で示される出力のように位置誤差 0 を中心に左右対称な出 力を得られることから，2つの一次元 PSD 出力の差分を取 ることで図 5(a), (b) の $\mathrm{PSD}_{X L}-\mathrm{PSD}_{X R}$ に示されるように 穴面との距離にかかわらず位置誤差 0 で一次元 PSD 出力 が常に 0 となる。本センサは縦・横軸両方向の位置誤差検 出が必要であることから, 各軸方向に 2 つずつ一次元 PSD を十字型に配置する構造とした。

図 7 に設計したセンサシステムの概観図を示す。一次元 PSD は浜松フォトニクス製PSDのS3932を使用した。十 字型に配された一次元 PSD を囲むように 64 個の赤外光 LED が取り付けられており，これによって穴面を照らす。 穴面から反射してくる反射光を，シリンドリカルレンズを 通して一次元 PSD の受光面に集光する構造となっている。
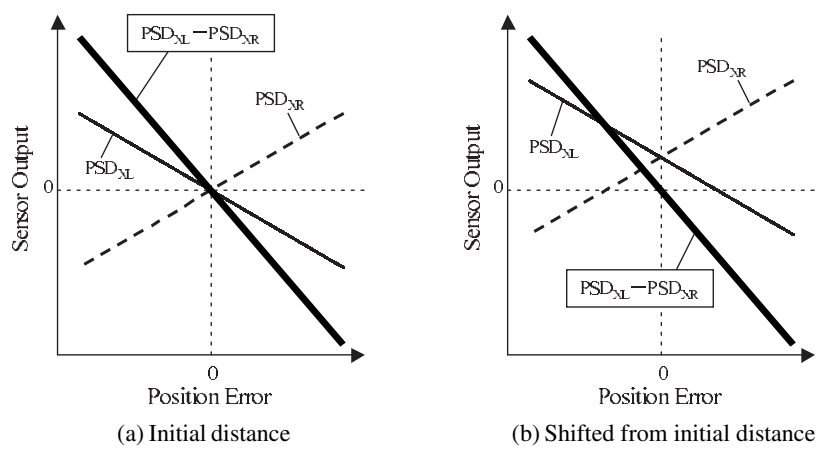

(b) Shifted from initial distance

困 5 距離によるセンサ出力の変化

Fig. 5. Senser output change for distance.

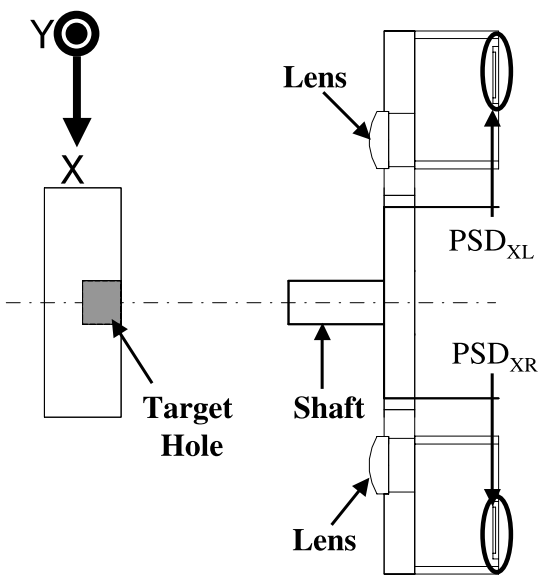

図 6 センサヘッド構造

Fig. 6. Configuration of the sensor head. 




困 7 一次元 PSD センサの構造

Fig. 7. Structure of one dimensional PSD sensor.

\section{3. 位置誤差検出センサ内蔵エンドェフェクタ}

前章で示したようにセンサシステム部が構成された。次 に，このセンサシステムを取り付けるエンドエフェクタ部 について検討を行なう。著者らが既に提案している軸挿入 作業時に軸挿入が失敗した際に，軸に螺旋振動を与えるこ とで挿入軸を正しい位置へ導くことが可能な振動型エンド エフェクタ(9) の方式を今回のエンドエフェクタにも採用す ることにした。その基本構造を図 8 に示す。挿入軸を 8 本 のバネで把持してコンプライアンス機構を実現している。 これによってある程度の位置誤差に対しても対応が可能な 構造となっている。また挿入軸の後退量を計測するための 二次元 PSD も取り付けてある。また従来アクリルで製作し ていたハウジングをアルミ製にして強度を強化した。製作 されたエンドエフェクタの外観を図 9 に示す。またこのエ ンドエフェクタに前節で示した一次元 PSD を十字型に配置 したセンサヘッドを搭載したものを位置誤差検出センサ内 蔵エンドエフェクタと呼ぶこととし，その外観を図 10 に 示す。挿入軸を吊り下げるハウジングと，そのハウジング 部に一次元 PSD が十字形状に取り付けられている構造と なっている。文献(9) のエンドエフェクタと唯一異なるの は, 軸に螺旋振動を加え半能動的に位置誤差補正を行なう 電磁駆動システムが搭載されていないことである。軸部は 八ウジング内部にばねで吊るされていることから，挿入失 敗時には軸が穴面より押し返され，軸を押しつける力が発 生することで，受動的な位置誤差補正能力を有することが 文献 (9) で確認されており，駆動システムは不要であると 判断した。こうしてセンサ重心と挿入軸重心を一致させる 構造が実現でき，従来の軸挿入システムでは不可能だった 軸挿入作業中の対象穴位置検出が可能となった。

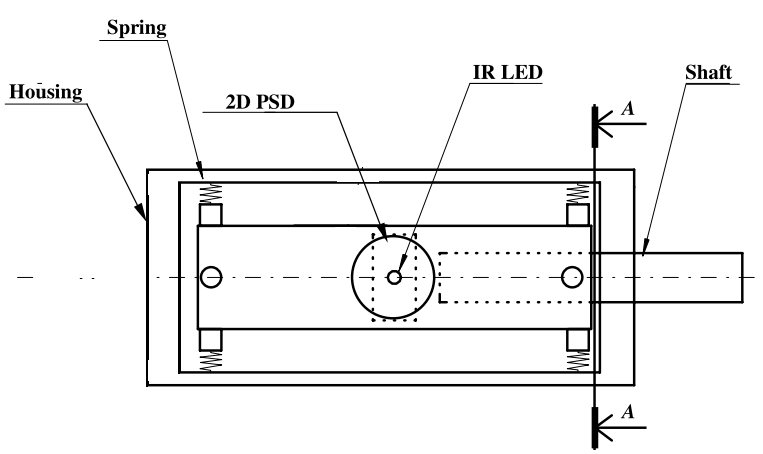

(a) Side View

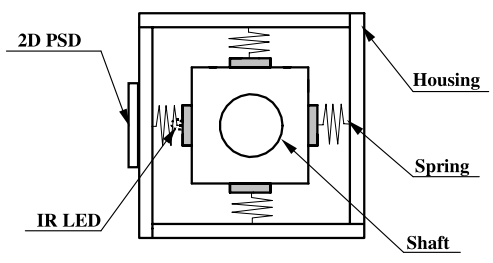

(b) Front View $\left(A-A^{\prime}\right)$

図 8 エンドエフェクタ構造

Fig. 8. Structure of the end effector.

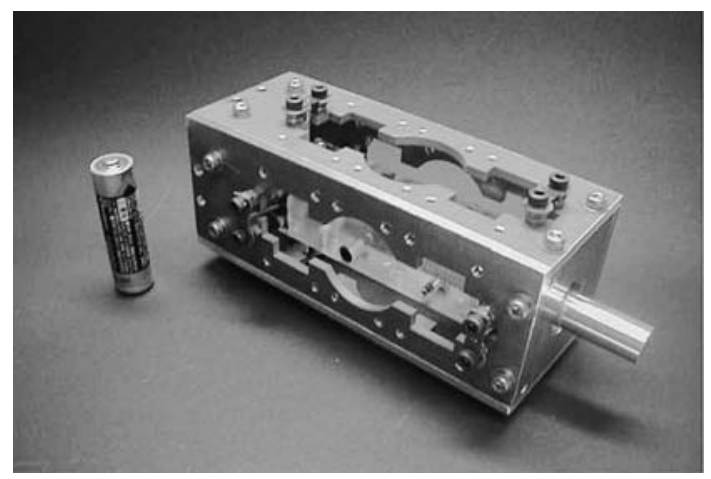

図 9 エンドエフェクタ外観

Fig. 9. Outside view of the end effector.

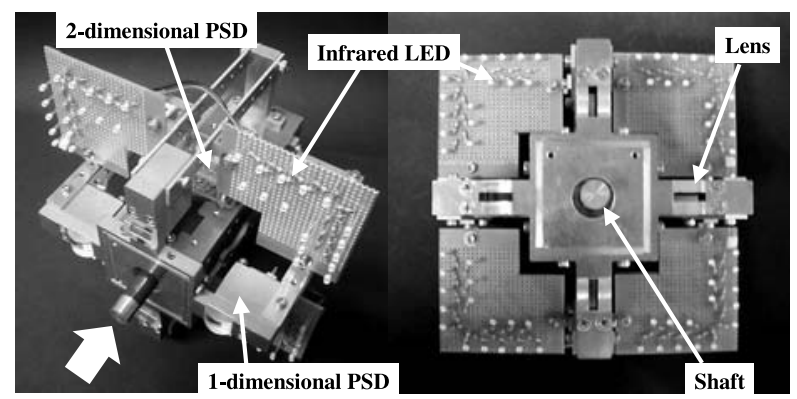

図 10 位置誤差検出センサ内蔵エンドエフェクタ外観

Fig. 10. Outside view of end effector with position error detecting sensor.

\section{4. 軸挿入実験システム}

前章で述べた，位置誤差検出センサ内蔵エンドエフェク 夕を取り付けた移動物体へのはめ合い作業用ロボットシス テムを構成した。図 11 に実験システムの外観を示す。本 




図 11 実験システム外観

Fig. 11. Outside view of experimental system.

実験システムは，軸挿入ロボットとして四自由度直交座標 型ロボット（YAMAHA 製 LS-850-100），挿入対象となる 穴面を取り付けた短軸ロボット（YAMAHA 製 LSII-850), 実験システム統合制御用 PC と大きく 3 つに分けられる。 本実験システムの構成図を図 12 に示す。PC は本システ ムの統合管理を行なうホストコンピュータであり統合制御 ソフトが動作しており，本体内部にはDSP と DIO が搭載 されている。DSP は MTT 社製 DSP4310を使用しており， $\mathrm{A} / \mathrm{D}, \mathrm{D} / \mathrm{A}$ と DIO を搭載している。DSP は一次元 PSD の 出力の受け取り，ロボット制御用のサーボパック（安川電 機製 CPCR-FR01RB7）へのフィードバック指令值の生成, ロータリーエンコーダの出力パルスのカウント，ロボット アームの位置情報獲得に使用している。DIO は短軸ロボッ 卜に対して動作開始指令を送るのに使用している。本実験 システムでは，短軸ロボットの位置情報や速度情報などは 一切使用されておらず，一次元 PSD から検出される対象穴 面の位置誤差情報のみを用いて制御を行なっている。一次 元 PSD の出力值の演算はアナログ回路にて演算処理回路を 作成し，そこで演算した結果を $\mathrm{A} / \mathrm{D}$ を通して PCに取り込 んでいる。演算処理回路では 2 章で示した一次元 PSDの 検出原理に従いリアルタイム演算を行っている。

$\mathrm{X}$ 軸制御系は図 13 に示されるように，軸挿入の状態に 応じて制御方式を切り替えるハイブリッド制御方式を用い ている。軸挿入初期段階においては，一次元 PSD の出力を 用いて追従制御を行なう。追従制御中に対象穴面との並走 状態となったことを検出すると, 軸挿入動作モードとなり, そのモードでは $\mathrm{X}$ 軸は速度制御に切り替えられる。 $\mathrm{Y}$ 軸制 御系は軸挿入時に位置制御動作を使って軸の挿入を行なう。

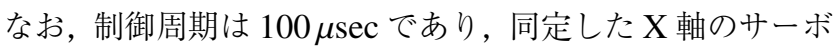
系（サーボパック入力からモー夕の速度出力まで）の伝達 関数 $G(z)$ は,

$$
G(z)=\frac{5.432 \times 10^{-3}(z-0.9796)}{z^{2}-1.987 z+0.9875}
$$

である。

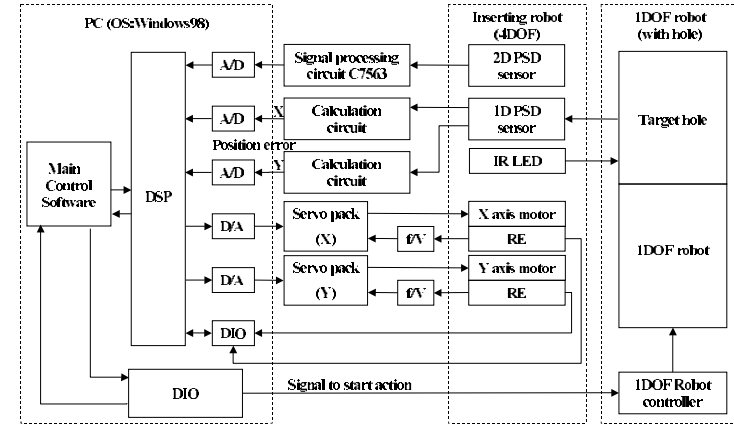

図 12 実験システム構成

Fig. 12. Configuration of experimental system.

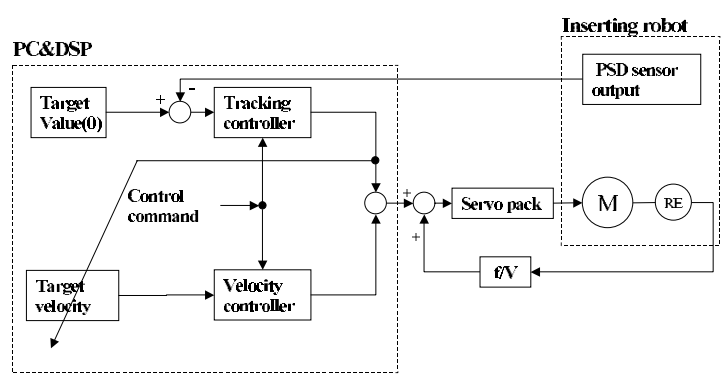

図 13 ロボットのサーボシステム（X 軸）

Fig. 13. Servo system of robot ( $\mathrm{X}$ axis).

\section{5. 実験結果}

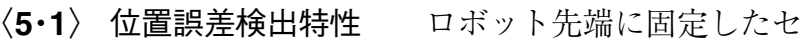
ンサシステムに対し穴面の位置を変化させていき，位置誤 差検出センサの出力特性の測定を行なった。図 14 に X 軸 方向のセンサの重心位置誤差に対する出力特性を示す。縦 軸はセンサ出力電圧, 横軸は重心位置誤差を表す。また実 験は穴面とセンサレンズ部までの距離が $70 \mathrm{~mm}, 60 \mathrm{~mm}$, $50 \mathrm{~mm}, 40 \mathrm{~mm}$ の場合の 4 つの距離で行った。距離 $40 \mathrm{~mm}$ までしか行っていないのは，その状態で軸の先端と穴面ま での距離 $15 \mathrm{~mm}$ であり，これ以上接近させると軸のために センサが穴の影を検知できなくなるからである。

この結果を見ると, 穴面とセンサの距離が変化しても, 位 置誤差 0 で出力 0 となっていることが確認できる。また, その出力特性より $\pm 12 \mathrm{~mm}$ の位置誤差範囲内で位置誤差を 0 とする制御に使用するセンサとして十分な特性を持ってい ることが分かる。位置誤差の大きさが $8 \mathrm{~mm}$ 以上になると 位置誤差に対するセンサ出力特性に変化が見られるが，セン サから得られる位置誤差情報を使って制御を行う上で問題 にならない特性変化である。また，穴面との距離が $40 \mathrm{~mm}$ 以下になると測定が行えなくなるが，その際の軸と穴面の 距離は $15 \mathrm{~mm}$ 以下である。従来の十字型 PSD センサでは 軸と穴面の距離が $58 \mathrm{~mm}$ であったことを考えれば，移動距 離が約 4 分の 1 となったことでセンサの観測不能時間が短 縮でき，問題の改善が実現できたと言える。

なお，Y 軸方向のセンサ出力についても同様の出力特性 が得られている。 


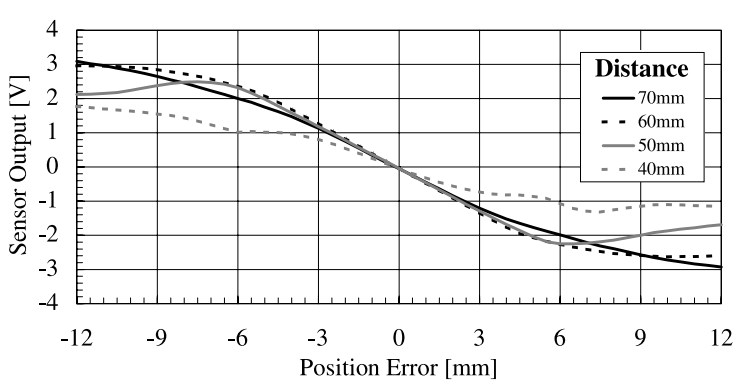

図 14 位置誤差検出の実験結果

Fig. 14. Experimental result of position error.

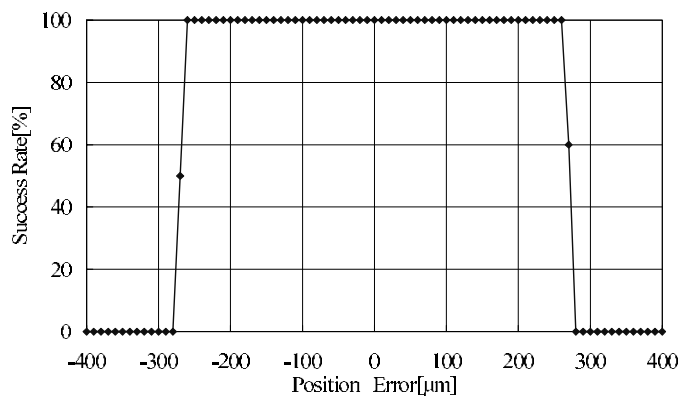

図 15 各位置誤差における成功率

Fig. 15. Success rate for each position error.

〈5・2〉 エンドェフェクタの位置誤差補正特性軸挿 入可能な軸と穴の位置誤差の補正可能範囲を調べる実験を 行った。軸と穴のクリアランス $50 \mu \mathrm{m}$ の穴面を静止させ, $\mathrm{X}$ 軸方向の軸と穴の位置誤差を任意值 $-400 \sim+400 \mu \mathrm{m}$ の 範囲で $10 \mu \mathrm{m}$ 毎に位置誤差を変化させていき，軸挿入を各 位置につき 10 回ずつ行いその成否を確認した。その結果 を図 15 に示す。本エンドエフェクタの $100 \%$ 軸挿入可能な 補正可能位置誤差の範囲は $-260 \sim+260 \mu \mathrm{m}$ という結果と なり，従来の振動型エンドエフェクタとほぼ同等の性能を 有していることが確認できた。

$\langle\mathbf{5} \cdot \mathbf{3}\rangle$ 移動物体への軸挿入実験和結果を踏まえ て移動物体に対する軸挿入実験を行った。軸挿入作業対象 穴面の移動速度は，著者が調査した中での産業用生産ライ ンの最高速度相当の $80 \mathrm{~mm} / \mathrm{sec}$ とし, 挿入軸径 $11.40 \mathrm{~mm}$, 軸と穴のクリアランス $50 \mu \mathrm{m}$ の実験条件で移動物体に対す る軸挿入作業実験を行なった。また，軸と穴面は互いに垂 直になっているものとする。一般的に軸と穴面には面取り が行われているものであるが，本実験システムでは面取り を行なっていない軸と穴面を使用しており，クリアランス 以内での位置決めが要求される挿入条件となっている。

まず，本センサが移動物体に対して安定な併走状態を実 現できるか確認のため予備実験を行った。予備実験では通 常の実験と異なり併走実現後に軸挿入動作モードに切り替 えても実際には軸挿入を行わず，PSD センサにて穴面との 位置誤差の計測を行い続けた。その結果を図 16 に示す。こ の図は横軸が時間を表し，縦軸がセンサ出力とロボットへ の制御入力指令值を表しており，(a) の結果が制御入力指令

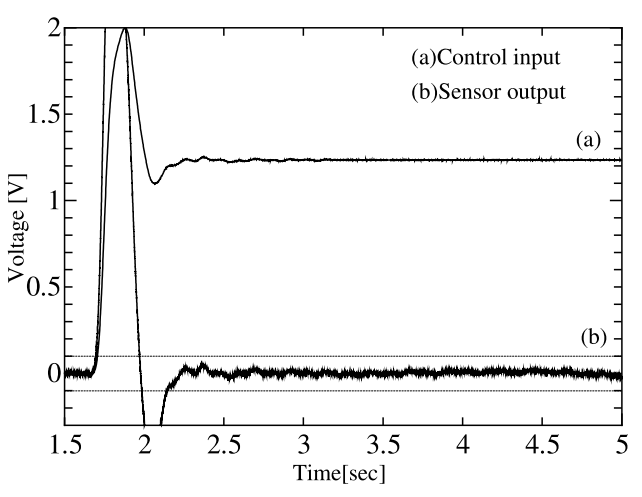

図 16 実験結果

Fig. 16. Experimental result.

值であり，(b)の結果がセンサ出力である。計測開始後 1.6 秒にて実験を開始し，3 秒付近にて併走状態に入ったとシ ステムが認識し制御系を軸挿入動作モードに切り替えてお り，その後，速度制御によりセンサ情報を用いること無く 併走が 2 秒間維持されていることが確認できる。この間の 位置誤差は本エンドエフェクタが対応可能な $260 \mu \mathrm{m}$ 以内 に収まっており（図中の $\pm 0.1 \mathrm{~V}$ が $250 \mu \mathrm{m}$ に相当），併走 中 2 秒間の最大誤差は $80 \mu \mathrm{m}$ であった。この結果より, 併 走状態を実現した後に軸挿入作業を行えば軸挿入が成功す ることが確認できる。

予備実験の結果を踏まえて, 移動穴面に対して10 回の試 行を行った結果 $100 \%$ 軸挿入に成功し, 本センサシステム の有効性が確認された。

\section{6. おわりに}

一次元 PSD を十字型に配置した位置誤差検出センサ内蔵 エンドエフェクタを提案・製作した。一次元 PSD を使用し た穴面位置誤差検出センサシステムの検出理論を明らかに し，センサ搭載エンドエフェクタシステムの製作を行った。 センサの出力特性試験より, 位置誤差検出特性は位置誤差 0 とする制御に使用可能な特性を持つことが確認され，また 対象穴面と PSD センサの距離が変動しても測定可能である ことから軸挿入作業中でもセンサが使用可能であることも 確認された。更に, 静止物体への軸挿入実験より $\pm 260 \mu \mathrm{m}$ 以内の位置誤差補正が可能であるエンドエフェクタである ことを確認した。ロボットシステムに取り付け移動物体へ の軸挿入実験を行い, 穴面移動速度 $80 \mathrm{~mm} / \mathrm{sec}$, 軸と穴の クリアランス $50 \mu \mathrm{m}$ の実験条件にて $100 \%$ 軸挿入に成功す ることを確認し, 位置誤差検出センサ内蔵エンドエフェク タシステムの有効性を確認した。

今後の課題としては，対象穴面が傾いていた場合にその 傾きを検出し，その傾斜に対応が可能となるよう本センサ の傾き角検出原理を導出し，実装することである。

本研究はダイハツ工業 (株) 青沼大輔氏の協力を得て実験 が行われた。ここに感謝の意を表する。また, 本研究は文部 科学省科学研究補助金 (若手研究 (B) 課題番号 13750401) 
による助成と文部科学省ハイテク・リサーチ・センター事 業（平成 15 年度〜平成 19 年度）による私学助成を受けて 行われたものである。

(平成 17 年 1 月 11 日受付，平成 17 年 7 月 19 日再受付)

文献

(1) E. Paulos and J. Canny: "Informed peg-in-hole insertion using optical sensors”, Proc. SPIE, Vol.2059, pp.346-355 (1993)

(2) H. Asada and Y. Kakumoto: "The dynamic analysis and design of a highspeed insetion hand using the generalezed centroid and vertual mass", Trans. ASME J. Dyn. Syst. Meas. Cont., Vol.112, pp.646-652 (1990)

(3) I. Goto, K. Takeyasu, and T. Inoyama: "Control Algorithm for Precision Insert Operation Robots", IEEE Trans. Syst. Man \& Cyberm., Vol.SMC-10, No.1, pp.19-25 (1980)

(4) D.R. Strip: "A passive mechanism for insertion of convex pegs", Proc. 1989 Int. Conf. on Robotics and Automation, pp.242-248 (1989)

( 5 ) S. Aoyagi, K. Kuwahara, T. Jinno, and M. Takano: "Proposal of Realizing Method of STS Control Based on Trajectory Planning and Trajectory Update and Experimetal Verification of Its Effectiveness by Employing an Open Architecture Robot", JRSJ, Vol.19, No.1, pp.131-141 (2001-1) (in Japanese)

青柳誠司・桑原一義・神野崇治・高野政晴 : 「軌道計画と軌道更新に 基づくSTS 制御の実現手法の提案とオープンアーキテクチャ型ロ ボットを用いたその有効性の実験的検証」, 日本ロボット学誌, 19, 1 , pp.131-141 (2001-1)

(6) N. Tsuchida, M. Komatsu, Y. Yamada, and K. Imai: "Hole position and inclination sensor with 2 dimensional PSD for automatic shaft inserting", $T$. IEE Japan, Vol.115-C, No.12, pp.1507-1513 (1995-12) (in Japanese) 土田縫夫・小松雅行・山田陽滋・今井孝二：「2 次元 PSD を用いた シャフト自動挿入のための穴の重心 ・傾き検出センサ」, 電学論 $\mathrm{C}$, 115, 12, pp.1507-1513 (1995-12)

( 7 ) N. Tsuchida, Y. Yamada, and H. Tsuzuki: "Hole position sensor applying a 2 dimensional PSD”, IEICE Trans., Vol.J71-C, No.12, pp.1483-1485 (198812) (in Japanese)

土田縫夫・山田陽滋・都築裕之：「2 次元 PSD を用いた穴位置検出 センサ」, 信学論誌, J71-C, 12, pp.1483-1485 (1988-12)

(8) S. Hayakawa, N. Tsuchida, and H. Tanaka: "Shaft Inserting into the Moving Object using Robot with the Cross Type PSD", T. IEEE Japan, Vol.120-C, No.4, pp.516-521 (2000-4) (in Japanese) 早川聡一郎・土田縫夫・田中 均:「十字型 PSD センサを装着した口 ボットによる移動物体へのはめ合い作業」, 電学論 C, 120, 4, pp.516-521 (2000-4)

(9) S. Hayakawa and N. Tsuchida: "Shaft Insertion for Moving Object Using Robot Manipulator with Cross PSD and Vibration End-effector", Journal of Robotics and Mechatronics, Vol.13, No.5, pp.470-476 (2001-5)

(10) S. Hayakawa, Y. Yamada, and N. Tsuchida: "Shaft Inserting into Moving Object by Using End-effector with Position Error Detecting Sensor",
Technical Meeting on Industrial Instrumentation and Control, IIC-03-49 pp.25-28 (2003-4) (in Japanese)

早川聡一郎・山田裕一・土田縫夫：「位置誤差検出センサ内蔵エンド エフエクタを用いた移動物体への軸挿入作業」, 電気学会研資, 産業 計測制御研資, IIC-03-49, pp.25-28 (2003-4)

(11) S. Hayakawa and N. Tsuchida: "Shaft Inserting into Inclined Hole of Moving Object by Using Cross PSD Sensor", T. IEEE Japan, Vol.123-C, No.11, pp.2003-2009 (2003-11) (in Japanese)

早川聡一郎・土田縫夫 :「十字型センサを用いた移動物体の傾斜穴 への軸挿入作業」, 電学論 C, 123, 11, pp.2003-2009 (2003-11)

山 田 裕 - (学生員) 1979 年生。2003 年豊田工業大学工学

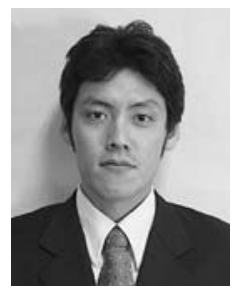
部制御情報工学科卒業。同年同大学院工学研究科 先端工学専攻修士課程入学, 現在に至る。移動物 体への軸挿入作業の研究に従事。計測自動制御学 会会員。

早 川 聡一郎 (正員) 1968 年生。1996 年 3 月名古屋大学工学

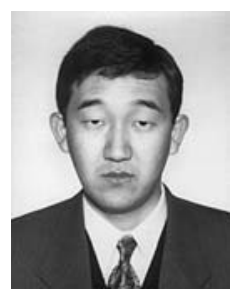
部電気工学研究科博士課程後期課程修了。同年豊 田工業大学助手, 現在に至る。博士 (工学)。主 としてロボット制御，知能制御に関する研究に従 事。ロボット学会, 電子情報通信学会, 計測自動 制御学会会員。

（正員） 1943 年生。1972 年名古屋大学工学部大 学院博士課程満了。同年同大学助手。1992 年豊 田工業大学教授, 現在に至る。工学博士。主とし てアクチュエータ, センサ，液体誘電物性及びそ の応用研究に関する研究に従事。電子情報通信学 会, 静電気学会, マイクロマシン研究会会員。 